ACTA VET. BRNO, 56, 1987: 305-313

THE IN VITRO EFFECTS OF ANTHELMINTICS ON THE ENZYME ACTIVITIES OF SETARIA CERVI

\title{
5. KUMAR
}

Department of Zoology, Institute of Advenced Studies, Meerut University, Meerut 250 005, U. P., India

Received November 4, 1986

\section{Abstract}

$K u m a r$.: The in vitro Effects of Anthelmintics on the Enzyme Activities of Setaria cervi. Acta vet. Brno, 56, 198.7: 305-313.

Effect of $E_{50}$ of 12 broad and narrow spectrum anthelmintics on acid (EC-3.1.3.2) and alkaline phosphomonoesterases (EC 3.1.3.1), adenosine triphosphatase (EC 3.6.1.3), glucose-6-phosphatase (EC 3.1.3.9.), fructose-1-6-diphosphatase (EC 3.1.3.11), malic enzyme (EC 1.1.1.38), cholinesterase (EC 3.1.1.8) and lactate dehydrogenase(EC 1.1.1.27), of males, females and microfilariae of Setaria cervi has been studied in vitro. A wide variety of effects were abserved which provide reliable clues to their mode of action which have been discussed.

Setaria cervi, filaria, nematode, anthelmintics, effect of, in vitro study, enzyme activities.

Several drugs have been found to profoundly influence metabolism of a number of endoparasites ( $v$ o $n$ B and 1973). If differences are found between the drug responses of the enzymes involved in the metabolism, of the host and the parasite, they may be exploited chemotherapeutically which will in turn be of help in controlling the parasite. With this view a series of investigations were undertaken. In the first phase of the studies the EC 50 levels of a variety of broad and narrow spectrum anthelmintics have been worked our ( $K$ u a r 1986), during a screen involving 23 anthelmintics and employing males, fenales and microfilariae of Setaria cervi, the most prevalent cattle filarial worm in Meerut region. The results of the second phase of the study revealing the effect of $E_{50}$ levels of 12 active anthelmintics on some of the key enzymes porticipating in metabolism, selected for the second phase, are now reported. 
Motile S. cervi were recovered from the peritoneal cavity of cattle slaughtered freshly in a local abattoir. They were washed thoroughly in physiological saline and the two sexes were separated. Microfilariae were recovered from the peripheral blood of the infected cattle by density gradient centrifugation on Percoll in $0.25 \mathrm{M}$ sucrose according to $\mathrm{Ch}$ andrashekar et al. (1984). Density of microfilariae was adjusted using dilution technique.

Male and female adults and microfilariae were axenized for 30 minutes in warm $\left(37^{\circ} \mathrm{C}\right)$ saline ( $\left.0.15 \mathrm{M}-\mathrm{NaCl}\right)$ containing antibiotics (penicillin, 124 ug; streptomycin, 70 ug; mycostatin, 100 units per ml). 150 adult worms (males and fembles separately) per $200 \mathrm{ml}$ of culture medium in stoppered Erlenmeyer flasks or 2,000 microfilariae per ml of culture medium in stoppered glass containers on a roller drum, were incubated for $16 \mathrm{~h}$ (adult) or for $4 \mathrm{~h}$ (microfilariae) in predetermined (unpublished observations) optimal conditions ( $5 \% \mathrm{CO}_{2} 10 \% \mathrm{O}_{2}$ and $85 \% \mathrm{~N}_{2} ; 38 \pm 1 \mathrm{C}$ ). The incuBiological Company, NY, USA) supplemented with either $0.0225 \mathrm{mg}$ glucose per ml (adults) or bovine serum ( $0.04 \mathrm{ml}$ per ml; microfilariae) and antibiotic mixture as described above + drug solution/suspension of predetermined $\mathrm{EC}_{50}(9: 1)$. Water insoluble drugs were dissolved in a suitable 281 atile solvent (acetone or diethyl ether) and a known volume was added to the container. After the solvent evaporated completely leaving a thin film of drug deposit over the basal surface of each container culture medium was added. Culture medium controls were prepared and treated identically with the exception that the drugs were not included. Males, females and microfilariae were incubated in the control culture media exactly as described above. The treated and untreated control worms were thoroughly washed and homogenized in de-ionized double distilled water for the following biochemical assays.

Bodansky s method (Bodansky 1972) was used for the assay of acid and alkaline phosphomonoesterases. Substrate used was $0.016 \mathrm{M}$ sodium $\beta$-glycerophosphate in the presence of diethyl barbiturate. Buffers used were prepared as follows: for $\mathrm{pH}$ range $1.5-7.0$ ( $0.1 \mathrm{M}$ sodium citrate - HCl buffer), for $\mathrm{pH}$ range $7.0-9.5$ ( $0.1 \mathrm{M}$ sodium veronal - HCl buffer), and for pH range $9.5-12.0$ (glycine - NaCl - NaOH buffer of Sorenson and Walbum). The reaction mixture for each experiment containing $2 \mathrm{ml}$ each of the substrate and buffer together with $0.4 \mathrm{ml}$ of enzyme supernatant of homogenate was incubated at $37^{\circ} \mathrm{C}$ for exactly $1 \mathrm{~h}$. $40 \%$ trichloroacetic acid (TCA) was added to stop the reaction. The amount of inorganic phosphate released was estimated according to $F$ iske and Subba Row (1925) at $673 \mathrm{~nm}$ using Sicospec-100 spectrophotometer. Protein was estimated in enzyme supernatant according to Low r y et al. (1951).

Adenosine triphosphatase was assayed according to $K$ i 11 e y (1955). Assay mixture contained $0.1 \mathrm{ml} 0.2 \mathrm{M}$ ATP, $0.2 \mathrm{M}$ histidine buffer $(\mathrm{pH} \mathrm{7.4),0.05} \mathrm{M} \mathrm{MgCl}, 0.4 \mathrm{ml}$ distilled and de-ionized water and $0.1 \mathrm{mi}$ enzyme. $50 x^{2}$ perchloric acid was used to stop the - reaction. Protein and phosphate were estimated as above.

Glucose-6-phosphatase was assayed according to $S$ wan s o $n$ (1955). The assay mixture contained $0.1 \mathrm{ml}$ homogenate, $0.3 \mathrm{ml}$ of maleic acid buffer and $0.1 \mathrm{ml}$ substrate. 10\% TCA was used to stop the reaction. Protein and phosphate were estimated as above. 
Fructose-1-6-diphosphatase was assayed according to M C Gilvery (1955). The react.on mixture contained $0.05 \mathrm{M}$ fructose diphosphate, $0.05 \mathrm{M}$ borate buffer, $0.05 \mathrm{M} \mathrm{MgSO}_{4}, 0.005 \mathrm{M} \mathrm{MnCl}_{2}$, $0.2 \mathrm{ml}$ of enzyme and $0.05 \mathrm{M}$ cysteine. Protein and phosphate ${ }^{2}$ were determined as above.

- Malic enzyme was assayed in the mitochondrial fraction according to $\mathrm{HSU}$ and $\mathrm{L}$ a r dy (1969) and cholinesterase in the supernatant fraction according to Beckendahl and Ammon (as cited in Bergmeyer 1974). Protein was estimated as before.

Lactate dehydrogenase was assayed according to Ko r n b e I $g$ (1955). Assay mixture contained tris-HCl ( $\left.\mathrm{pH}^{7.4}\right), 0.2 \mathrm{M} \mathrm{KCl}$, $0.1 \mathrm{M}$ sodium pyruvate, $0.005 \mathrm{M} \mathrm{NADH}$ and $0.1 \mathrm{ml}$ of enzyme. Protein was estimated as before.

Student's t-test was used to determine the significance of differences between values obtained for tests and corresponding controls. In addition to parameter of statistical significance, parameter of biochemical significance was also assigned. Those anthelmintics that inhibited or activated the anzyme activity by $40 \%$ or more were regarded as potent inhibitors or potent activators. To determine $40 \%$ or less or more inhibition or activation, the mean values of the drug effect obtained for males, females or microfilariae for individual anthelmintic were utilized. All chemical used (E. Merck, Germany/BDH, England) were of analytical grade and de-ionized, double distilled water was used for the preparation of all the reagents.

$R$ es $s$ l t s

Results obtained are summarised in Tables 1,2 and 3 .

Table 1

Enzyme activities in untreated control adult and microfilarial stages of Setaria cervi

\begin{tabular}{|c|c|c|c|}
\hline \multirow[t]{2}{*}{ Enzyme } & \multicolumn{3}{|c|}{$\frac{\text { Specific activity (units/mg protein) }}{\operatorname{Mean}(N=5) \pm 5.0 .}$} \\
\hline & Male & Female & Microfilariae \\
\hline $\begin{array}{l}\text { Acid phosphatase } \\
\text { Alkaline phosphatase } \\
\text { Adenosine triphosphatase } \\
\text { Glucose-6-phosphatase } \\
\text { Fructose-1-6-diphosphatase } \\
\text { Malic enzyme } \\
\text { Cholinesterase } \\
\text { Lactate dehydrogenase }\end{array}$ & $\begin{array}{c}33.81+0.34 \\
35.7 \pm 1.04 \\
2.02 \pm 0.01 \\
22.73 \pm 1.2 \\
23.64+2.74 \\
0.37 \pm 0.001 \\
37.39 \pm 1.3 \\
2267 \pm 10.7\end{array}$ & $\begin{array}{c}35.13+0.07 \\
40.31 \pm 1.30 \\
3.21 \pm 0.006 \\
21.74+0.9 \\
20.30 \pm 1.08 \\
0.41 \pm 0.09 \\
39.35 \pm 0.8 \\
2675 \pm 9.24\end{array}$ & $\begin{array}{c}38.19+0.86 \\
48.92 \pm 1.70 \\
2.98 \pm 0.002 \\
24.51 \pm 1.4 \\
23.91 \pm 0.97 \\
0.46 \pm 0.003 \\
57.84 \pm 1.1 \\
2681 \pm 14.89\end{array}$ \\
\hline
\end{tabular}

Almost all the anthelmintics studied presently inhibited the activity of acid and alkaline phosphomonoesterases to different extents, with the exception of phenothiazine which did not show 


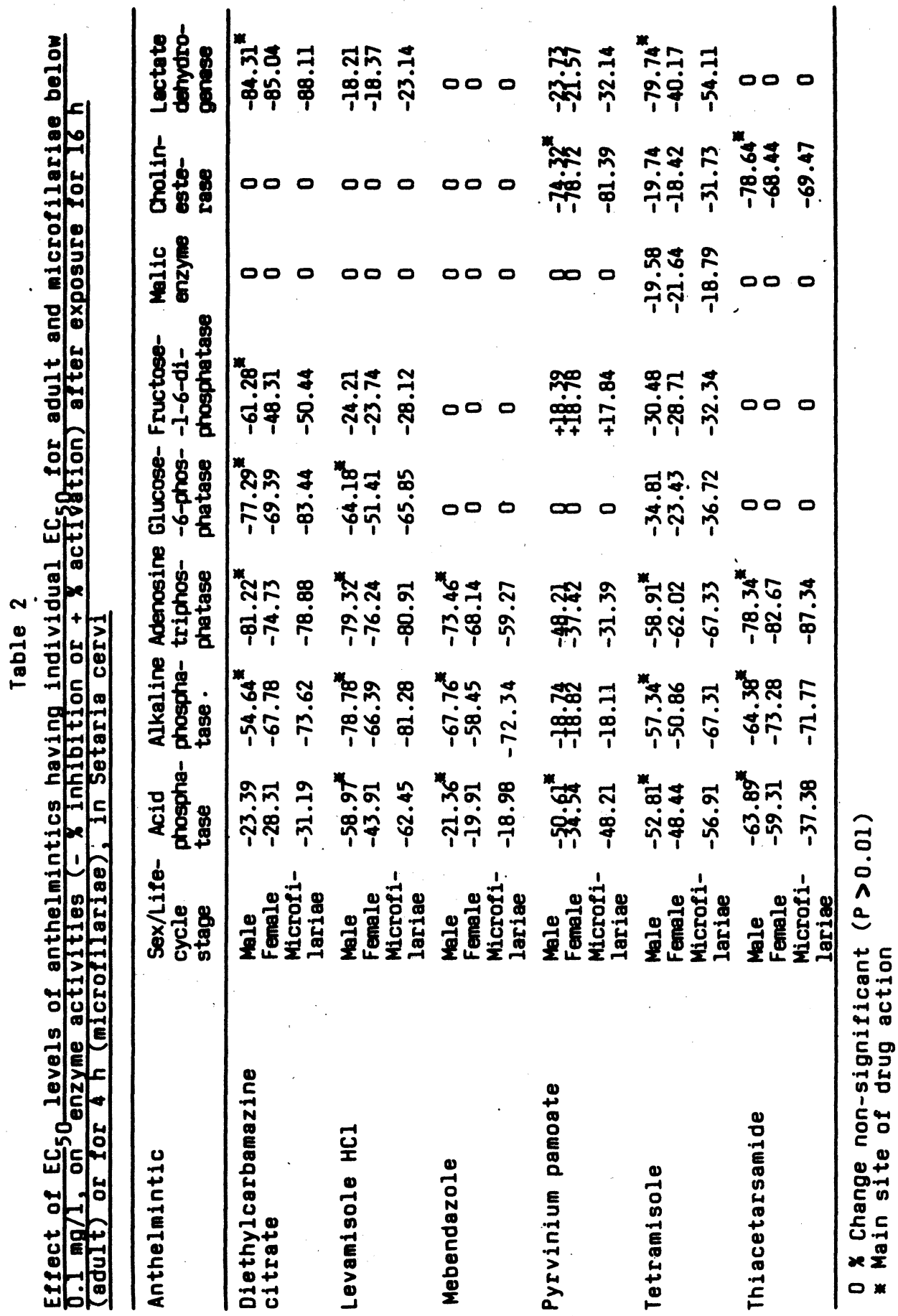


any statistically significant change $(P>0.01)$. For acid (ivermectin), levamisole, piperazine hexahydrate, pyrvinium pamoate, suramin, tetramisole and thiacetarsanide) and alkaline (bephenium, diethyl carbamazine, ivermectin, levamisole, mebendazole, piperazine hexahydrate, suramin, tetramisole and thiacetarsamide). phosphomonoesterases, adenosine triphosphatase (diethylcarbamazine, ivermectin, levamisole, mebendazole, piperazine hexahydrate, tetramisole, thiabendazole and thiacetarsamide), glucose-6-phosphatase (diethylcarbamazine, levamisole and thiabendazole), fructose-1-6-diphosphatase (diethylcarbamazine and suramin), malic enzyme (ivermectin and suramin), cholinesterase (ivermectin, piperazine hexahydrate, pyrvinium pamoate, suramin and thiacetarsamide) and lactate dehydrogenase (diethylcarbamazine, phenothiazine and tetramisole) different drugs were found to be potent inhibitors. Bephenium, however, was a potent activator to cholinesterase.

\section{Discussion}

A clear understanding of the biochemical reactions, particularly those of carbohydrate metabolísm in the helminth tissues, is essential for delineation of the anthelmintic action of chemotherapeutic agents ( $v$ on B r a nd 1973). Results obtained presently indicate that all the 12 drugs ar $E_{50}$ (reported elsewhere, Kumar 1986) greatly influence energy metabolism of S. cervi involving both carbohydrate as well as lipid metabolism with the exception of diethylcarbamazine, levamisole, mebendazole and thiabendazole which exert their influence on carbohydrate metabolism only. Though phenothiazine and tetramisole influence lipid metabolism to a small degree, not being potential inhibitors of cholinesterase, they exert their main effects on carbohydrate metabolism. Chief sites of drug action are marked in Tables 1 and 2. Acetylcholine is involved in nervous transmission in nematodes and cholinesterase serves to destroy the transmitter, as it does in other animal groups ( $L$ e e 1965). Pharmacological and biochemical studies have suggested that the sustained contraction results from a depolarising type of neuromuscular blockage ( $C$ o les et al. 1975). This blockage may ultimately be due to nerve transmission which is sustained by inhibition or reduction of the cholinesterase activity by various anthelmintics listed above, in $S$. cervi. Malic enzyme is one of the enzymes involved in $\mathrm{CO}_{2}$ fixation and its presence suggests an alternate fate of phosphoenolpyruvate and ATP is generated when the latter is reduced to form puruvate. Glucose-6-phosphatase, fructose-1-6-diphosphatase and lactate dehydrogenase are the key enzymes of carbohydrate metabolism and their inhibition indicates serious blockage of glycolysis. In addition to these enzymes, inhibition of acid and alkaline phosphomonoesterases and ATPase point townd a major set back to ATP turn-over and hence to the energy metabolism as a whole. On the basis of the potent influence of the drugs on diffecent enzymes, they may be arranged in the following decreasing order of effectiveness:

drug affecting maximum number $(\dot{s})$ of enzymes (diethylcarbamazine citrate, ivermectin and suramin) drug affecting 4 enzymes (leva- 


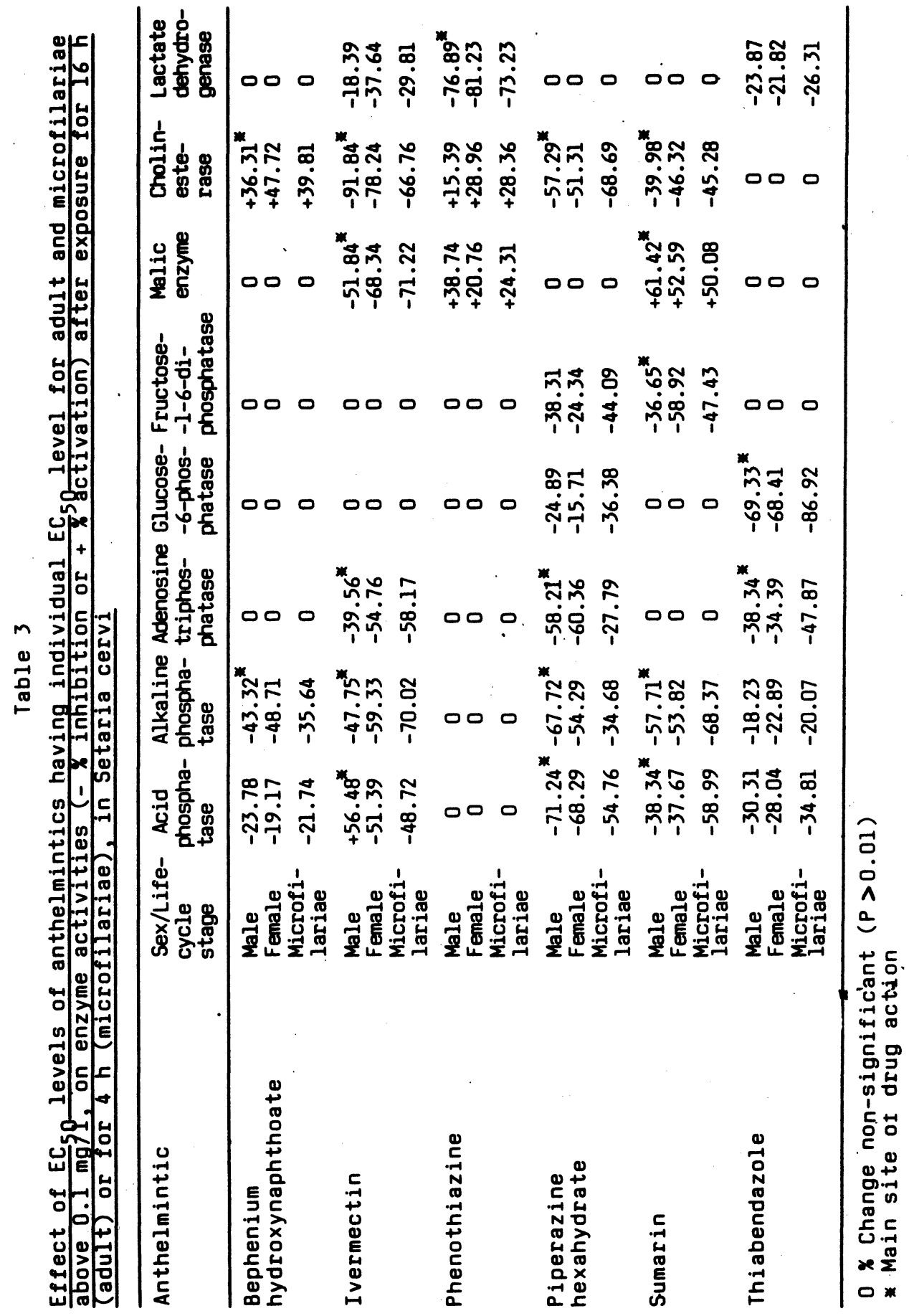


misole, piperazine, tetramisole and thiacetarsamide) drugs affecting 2 enzymes (bephenium, mebendazole, pyrvinium pamoate and thiabendazole) drug affecting l-enzyme (phenothiazine).

Antinematodal activity of all the 12 drugs studied presently has been reported in a variety of parasitic nematode species such as Ascaris, Ancylostoma, Litomosoides carinii, Wuchereria bancrofti, Nippostrongylus brasiliensis, Nematospiroides dubius, Haemonchus contortus, Trichostrongylus colubriformis and Ostertagia ostertagi (Thienpont et al. 1966; Lammler et al. 1971; $Z a m a n$ and $L$ a 1 1973; I $\quad$ b r a and Jenkins 1984). The biochemical differences between the parasite and its host form a basis for the selective toxicity of anthelmintic drugs $S$ a $Z$ and Bueding 1966). Although a good deal of information is now available about anthelmintics and their action in vivo particularly regarding their effects on energy metabolism and neuromuscular system (S a 2 1970), very little is known about their in vitro action (de l C a s t ill o 1969). Reports, however, are available which indicate that anthelmintics strongly inhibit a variety of enzyme systems of the worms. Cholinesterase, aldolase, fumarate reductase, lactate dehydrogenase, malate dehydrogenase and phosphatase activities of Ascaridia galli, H. contortus, $A$. suum, Dirofilaria immitis and Onchocerca volvulus have been reported to be inhibited by a variety of anthelmintics such as levamisole, tetramisole, parachloric benzoate, suramin and piperazine (Govorova and Poljakova 1971; Kurilenko 1971; Vertinskaya et al. 1972; Chakraborty et al. 1976; Wa 1 ter 1979; Wa 1 ter and Schulz-Key 1980).

Though it appears that the above discussed metabolic disturbances are the chief factors contributing to the lethal effects of the anthelmintics on $S$. cervi, the possibility may not be excluded that the drugs may also be active against other mechanisms essential for surviva: of the worms. It can be very safely inferred from the results obtained that diethylcarbamazine citrate is the most effective drug and is regarded to be a drug of choice against filariasis due to $S$. cervi as it affects maximum number of enzymes at lowest concentrations used. I therefore conclude that simple, straightforward in vitro studies such as these described here afford useful means for the initial selection of more effective anthelmintics against filariasis.

Acknowledgements: The author is grateful to Dr. S. S. Lal, Reader, and Professor, K. C. Pandey, Head, Department of Zoology, Meerut University, Meerut, for the facilities. Uxinky anthelmintik in vitro na aktivitu enzymú
Setaria cervi

In vitro byl siedován vliv $\mathrm{EC}_{50}$ dvanácti anthelmintik se sirokým a úzkým spektrm úcinku na kygelou a alkalickou fosfomonoesterázu, adenosín trifosfatázu, glukózo-6-fosfatázu, froktózo-1-6-difosfatázu, malátdehydrogenázu, cholinesterázu a laktátdehydrogenázu $v$ homogenizovaných tẻlech sameckú, samicek a mikrofilárif Seta- 
ria cervi. Cetné vlivy studovaných substanci poskytuji spolehlivé vodítko pł̇i sledováni účinkủ diskutovaných anthelmintik.

Действие антигельминтозных препаратов ин витро на активность энзимов Setaria cervi

В пробирке проводили исследования влияния $\mathrm{EC}_{50}$ двенадцати антигельминтозных препаратов широкого и узкого диапазона денствия на кислую и шелочную фосфомоноэстеразу, аденозинтрифосфатазу, глюхозо-6-фосфатазу, Фрухтозо-1-6-дифосфатазу, малатдегидрогенаэу, холинэстеразу и лахтатдегидрогеназу в усредненных телах самцев, самох и михрофилярии Setaria cervi. Многочислениые фахтпры влияние исследуемых веществ являются надежным в ходе исследования воздействия обсуждаемых антигельминтозных препаратов.

References.

BERGMEYER, H. U.: Methods of enzymatic analysis. Vol.. 2. Academic Press, New York. pp. 831-851 (1974).

BODANSKY, 0.: In: 0. BODANSKY, A. L. LATNER, Editors, Advances in clinical chemistry. Academic Press, New York. pp. 43 (1972).

CHAKRABORTY, A. K. - MEHTA, R. K. - DATTA, I. C.: Effect of tetramisole upon certain biochemical constituents of Ascaridia galli. Ind. J. Exp. Biol. 14, 1976: 585-587.

CHANDRASHEKAR, R. - RAO, U. R. - RAJASEKARIAH, G. R - SUBRAHMANYAM, D.: Separation of viable microfilariae free of blood cells on Percoll gradients. J. Helminthol. 58, 1984: 69-70.

COLES, G. C. - EAST, J. M. - JENKINS, D. C.: The mechanism of action of the anthelmintic levamisole. Gen. Pharmacol. 6, 1975: 309-313.

Del CASTILLO, J.: Pharmacology of nematodes. In: M. Florkin, B. T. Scheer, Editors, Chemical Zoology. Vol. III. Academic Press, New York. pp. 521-554 (1969).

FISKE, C. H. - SUBBA ROW, Y.: The colorimetric determination of phosphorus. J. Biol. Chem. 66, 19.25: 375-400.

GoVorova, S. V. - POL JAKOVA, D. I.: Effect of tetramisole (Nilverm) on certain enzymes of Ascaridia galli. Trudy vsesoszn. Inst. Gel mintol. 17, 1971: 201-202.

HSU, R. - LARDY, H. A.: Malic enzyme. In: J. M. Lowestein, Editor, Methicids in enzymology. Vol. XIII. Academic Press, New York. pp. 1214-1219 (1969).

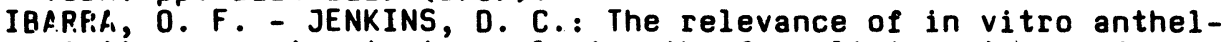
mintic screening tests employing the free-living stages of trichostrongyid nematodes. J. Helminthol. 58, 1984: 107-112.

KILLEY, W. W.: Mg-activated muscle ATPase. In: S. P. Colowick, N. O. Kaplan, Editors, Methods in enzymology. Vol. II. Academic Press, New York. pp. 588-591 (1955). 
KORNBERG, A.: Lactate dehydrogenase in muscle. In: S. P. Colowick and N. O. Kaplan, Editors, Methods in enzymology. Vol. I. Academic Press, New York. pp. 441-443 (1955).

KURILENKO, R. P.: Activity of lactate dehydrogenase in the tissues of Ascaris suum and Fasciola hepatica. Trudy vsesojozn. Inst. Gel mintol. 17, 1971: 79-80.

LAMMLER, G. - HERZOG, H. - SCHUTZE, H. R.: Chemotherapeutic studies on Litomosoides carinii infection in Mastomys natelensis. Bull. W.H.O. 44, 1971: 757-768.

LEE, D. L.: The physiology of nematodes. Oliver and Boyd, London (1965).

LOWRY, O. M. - ROSEBROUGH, N. J. - FARR, A. L. - RANDALL, R. J.: Protein measurement with folin phenol reagent. J. Biol. Chem. 193, 1951: 265-275.

Mc GILVERY, R. W.: Fructose-1-6-diphosphatase from liver. In: S. P. Colowick, N. O. Kaplan, Editors, Methods in enzymology. Vol. II. Academic Press, New York. pp. 543-546 (1955).

SANJEEV KUMAR: The response of adults and microfilariae of Setaria cervi in vitro to anthelmintics. Under communication, Acta Tropica (1986).

SAZ, H. J.: Comparative energy metabolism of some parasitic helminths. J. Parasitol. 4, 1970: 634-642.

SAZ, H. J. - BUEDING, E.: Relationships between anthelmintic effects and biochemical and physiological mechanism. Pharmacol. Rev. 16, 1966: 871-894.

SWANSON, M. A.: Glucose-6-phosphatase from liver. In: S. P. Colowick, N. O. Kaplan, Editors, Methods in enzymology. Vol. II. Academic Press, New York, pp. 541-543 (1955).

THIENPONT, et al.: Tetramisole a new potent broad spectrum anthelmintic. Nature, London 208, 1966: 1084-1086.

VERTINSKAYA, M. K. - GOVOROVA, S. V. - POLJAKOVA, O. I.: The inhibition of Ascaridia galii enzymes by tetramisole. Bjull. vsesojuzn. Inst. Gel mintol. 7, 1972: 9-12.

Von BRAND, T.: Biochemistry of parasites. Academic Press, New York.

WALTER, R. D.: Inhibition of lactate dehydrogenase activity of Dirofilaria immitis by suramin. Z. Tropenmed. Parasitol. 30, 1979: $463-465$.

WALTER, R. D. - SCHUTZE-KEY: In: H. van den Bossche, Editor, The host invader interplay. Elsevier, Amsterdam. pp. 709-712 (1980).

ZAMAN, V. - LAL, M.: Treatment of Wuchereria bancrofti with levamisole. Trans. Roy. Soc. Trop. Med. Hyg. 67, 1973: 610. 